\title{
Einfluß der verwendeten Methoden bei der Bestimmung von Ballaststoffen und verwertbaren Kohlenhydraten auf die Berechnung des Energiegehalts von Broten
}

Elisabeth Wisker und Walter Feldheim

Institut für Humanernährung und Lebensmittelkunde der Universität Kiel, Düsternbrooker Weg 17-19, 2300 Kiel, Bundesrepublik Deutschland

The Effect of Methods Used for the Determination of Dietary Fiber and Available Carbohydrates on the Calculation of the Physiological Fuel Value of Breads

Z Lebensm Unters Forsch (1984) 179:333-340

Tabelle 7. Energiegehalt von Broten, berechnet nach verschiedenen Methoden, in kcal/100 g

\begin{tabular}{|c|c|c|c|c|c|c|c|}
\hline \multirow[t]{2}{*}{ Brottyp } & \multicolumn{7}{|c|}{ Methode $^{\mathrm{a}}$} \\
\hline & I & II & III & IV & $\mathrm{V}$ & VI & VII \\
\hline Weizenbrot A & 275 & 271 & 262 & 258 & 278 & 280 & 268 \\
\hline Weizenbrot B & 253 & 248 & 241 & 236 & 255 & 257 & 241 \\
\hline Weizenbrot mit Kleie & 260 & 251 & 254 & 245 & 254 & 255 & 244 \\
\hline Weizenmischbrot A & 232 & 226 & 227 & 221 & 228 & 229 & 215 \\
\hline Weizenmischbrot B & 233 & 224 & 228 & 219 & 230 & 232 & 224 \\
\hline Weizenmischbrot $\mathrm{C}$ & 234 & 227 & 229 & 222 & 226 & 227 & 210 \\
\hline Weizenmischbrot mit Kleie & 224 & 212 & 210 & 199 & 213 & 214 & 199 \\
\hline Weizenschrotbrot & 226 & 209 & 219 & 203 & 215 & 217 & 204 \\
\hline Weizenvollkornbrot & 229 & 213 & 215 & 200 & 217 & 219 & 213 \\
\hline Weizenschrotbrot mit Kleie & 215 & 192 & 201 & 180 & 200 & 201 & 189 \\
\hline Roggenbrot & 225 & 215 & 209 & 200 & 214 & 215 & 204 \\
\hline Roggenbrot mit Kleie & 215 & 199 & 203 & 187 & 203 & 204 & 188 \\
\hline Roggenmischbrot A & 228 & 219 & 222 & 213 & 219 & 220 & 206 \\
\hline Roggenmischbrot B & 223 & 214 & 217 & 208 & 216 & 217 & 211 \\
\hline Roggenmischbrot mit Vollkorn & 223 & 208 & 216 & 201 & 211 & 213 & 199 \\
\hline Roggenmischbrot mit Kleie & 216 & 204 & 204 & 192 & 202 & 203 & 185 \\
\hline Roggenschrotbrot & 224 & 204 & 211 & 192 & 208 & 209 & 190 \\
\hline Roggenvollkornbrot A & 214 & 199 & 202 & 188 & 198 & 199 & 186 \\
\hline Roggenvollkornbrot B & 220 & 203 & 208 & 191 & 200 & 201 & 189 \\
\hline Roggenvollkornbrot C & 225 & 208 & 212 & 196 & 206 & 207 & 199 \\
\hline Roggenvollkornbrot D & 222 & 203 & 208 & 190 & 193 & 194 & 193 \\
\hline Roggenvollkornbrot E & 202 & 187 & 190 & 176 & 182 & 183 & 167 \\
\hline Roggenschrotbrot mit Kleie & 213 & 190 & 201 & 178 & 195 & 196 & 172 \\
\hline Spezialbrot & 207 & 170 & 194 & 162 & 171 & 172 & 161 \\
\hline Knäckebrot $\mathrm{A}$ & 371 & 339 & 349 & 319 & 332 & 334 & 326 \\
\hline Knäckebrot B & 367 & 338 & 346 & 318 & 333 & 335 & 313 \\
\hline Knäckebrot C & 362 & 338 & 341 & 318 & 327 & 329 & 309 \\
\hline
\end{tabular}

${ }^{a}$ Erläuterungen zu den Methoden

I: Protein/Fett/Kohlenhydrate Diff(Robfaser) $: 4 / 9 / 4$

II: Protein/Fett/Kohlenhydrate Diff(NDF-Methode) $: 4 / 9 / 4$

III: Protein/Fett/Kohlenhydrate ${ }_{\text {Diff(Rohfaser) }}$ : spez. Faktoren

IV: Protein/Fett/Kohlenhydrate ${ }_{\text {Diff(NDF-Methode) }}$ : spez. Faktoren

V: Protein/Fett/Kohlenhydrate ${ }_{\text {Diff(Ballaststofe) }}:($ Monosaccharide) $: 4,55 / 9,3 / 3,75$

VI: Protein/Fett/Kohlenhydrate Diff(Ballaststoffe) $: 4,55 / 9,3 / 4,2$

VII: Protein/Fett/Kohlenhydrate anal. (Monosaccharide) $: 4,55 / 9,3 / 3,75$ 